Article

\title{
Antihypertensive Effects of Two Novel Angiotensin I-Converting Enzyme (ACE) Inhibitory Peptides from Gracilariopsis lemaneiformis (Rhodophyta) in Spontaneously Hypertensive Rats (SHRs)
}

\author{
Zhenzhen Deng ${ }^{1,2,3,4,+}$, Yingjuan Liu ${ }^{1,2,3,4,+}$, Jing Wang ${ }^{1,2,3,4}$, Suhuang $\mathrm{Wu}^{1,2,3,4}$, \\ Lihua Geng ${ }^{1,2,3,4}$, Zhenghong Sui ${ }^{5, *}$ and Quanbin Zhang ${ }^{1,2,3,4, *}$ \\ 1 CAS Key Laboratory of Experimental Marine Biology, Institute of Oceanology, Chinese Academy of Sciences, \\ Qingdao 266071, China; dengzhenzhen16@mails.ucas.ac.cn (Z.D.); liuyingjuan829@163.com (Y.L.); \\ jingwang@qdio.ac.cn (J.W.); wusuhuang16@mails.ucas.ac.cn (S.W.); genglihua13@mails.ucas.ac.cn (L.G.) \\ 2 Lab for Marine Biology and Biotechnology, Qingdao National Lab for Marine Sci. \& Tech, \\ Qingdao 266071, China \\ 3 University of Chinese Academy of Sciences, Beijing 100049, China \\ 4 Center for Ocean Mega-Science, Chinese Academy of Sciences, 7 Nanhai Road, Qingdao 266071, China \\ 5 College of Marine Life Sciences, Ocean University of China, Qingdao 266071, China \\ * Correspondence: suizhengh@ouc.edu.cn (Z.S.); qbzhang@qdio.ac.cn (Q.Z.); \\ Tel./Fax: +86-532-8203-1128 (Z.S.); +86-532-8289-8703 (Q.Z.) \\ + These authors contributed equally to this work.
}

Received: 23 July 2018; Accepted: 21 August 2018; Published: 27 August 2018

\begin{abstract}
A variety of biologically active products have been isolated from Gracilariopsis lemaneiformis. In the present study, two novel angiotensin-converting enzyme (ACE) inhibitory peptides, FQIN $[\mathrm{M}(\mathrm{O})] \mathrm{CILR}$, and TGAPCR, were screened and identified from G. lemaneiformis protein hydrolysates by LC-MS/MS. The IC50 values of FQIN [M(O)] CILR and TGAPCR were $9.64 \pm 0.36 \mu \mathrm{M}$ and $23.94 \pm 0.82 \mu \mathrm{M}$, respectively. In the stability study, both peptides showed stabilities of $\mathrm{pH}$, temperature, simulated gastrointestinal digestion, and ACE hydrolysis. The Lineweaver-Burk plot showed that the two peptides were noncompetitive inhibitors of ACE. Molecular docking simulated the intermolecular interactions of two peptides and $\mathrm{ACE}$, and the two peptides formed hydrogen bonds with the active pockets of ACE. However, FQIN $[\mathrm{M}(\mathrm{O})]$ CILR was more closely linked to the active pockets of ACE, thereby exerting better ACE inhibition. Spontaneously hypertensive rats (SHRs) were studied with an oral dose of $10 \mathrm{mg} / \mathrm{kg}$ body weight. Both peptides reduced systolic blood pressure (SBP) and diastolic blood pressure (DBP) in SHRs, of which FQIN [M(O)] CILR was able to reduce the systolic blood pressure by $34 \mathrm{mmHg}(\mathrm{SBP})(p<0.05)$. Therefore, FQIN $[\mathrm{M}(\mathrm{O})]$ CILR was an excellent ACE inhibitory peptide.
\end{abstract}

Keywords: Gracilariopsis lemaneiformis; ACE-inhibitory activity; peptide; molecular docking; SHRs

\section{Introduction}

Hypertension (high blood pressure) refers to the main feature of increased body circulation arterial blood pressure (systolic blood pressure $\geq 140 \mathrm{mmHg}$ and diastolic blood pressure $\geq 90 \mathrm{mmHg}$ ), which is associated with increased mortality of cardiovascular disease and diabetes [1]. The WHO reported that more than 17.5 million people have died each year as a result of cardiovascular disease. Hypertension has become the leading global cause of death [2]. Human blood pressure is mainly regulated by the systemic renin-angiotensin system (RAS) and the kallikrein-bradykinin system (KKS). The role of the renin-angiotensin system in regulating blood pressure relies on the proteolytic 
cascade of two enzymes: renin (EC 3.4.23.15), an aspartyl protease secreted into the blood from the liver, and angiotensin I-converting enzyme (ACE; EC 3.4.15.1), a carboxypeptidase present on the external surface of endothelial cells of the lung [3]. Renin hydrolyzes the angiotensinogen ( $\alpha$-globulin) secreted by the liver to the inactive angiotensin I. Next, angiotensin I is hydrolyzed by ACE to angiotensin II, which then binds to angiotensin receptors and causes vasoconstriction [4]. In addition, ACE can inactivate bradykinin, a nonapeptide with cardiac protection. When bradykinin binds to $\beta$-receptor, a series of reactions are generated and causes the intracellular $\mathrm{Ca}^{2+}$ levels to increase significantly. $\mathrm{Ca}^{2+}$ stimulates the nitric oxide synthase (eNOS) reaction to produce NO, which results in vasodilation and reduced blood pressure [5]. Angiotensin I-converting enzyme is a ubiquitous $\mathrm{Zn}^{2+}$-dependent carboxydiopeptidase in mammalian tissues that regulates the renin-angiotensin system (RAS) and the kallikrein-bradykinin system (KKS) and is considered useful therapeutic target for treating hypertension [6-8]. The common ACE inhibitors on the market are mostly "Prils", such as captopril, enalapril, lisinopril, fosinopril and the like. While these drugs can produce a strong antihypertensive effect, they may also cause a series of side effects such as cough, rash, nausea, acute renal failure, and proteinuria. These drugs are believed to reduce patients' compliance, leading eventually to exacerbated disease conditions, and increased health care costs [9]. For this reason, researchers are increasingly interested in developing natural ACE inhibitory peptides with low-toxicity that could replace or complement antihypertensive drugs [10]. Food-derived active peptides not only produce the same activity as ACE inhibitor drugs but are also safer in terms of having low toxicity due to their natural source. Components of proteins in food are containing sequences of bioactive peptides, which could exert a physiological effect in the body. These short chains of amino acids are inactive within the sequence of the parent protein, but can be released during gastrointestinal digestion, food processing, or fermentation [11]. It has been reported that ACE inhibitory peptides obtained from enzymatic, fermentative, or gastrointestinal digestion of foods exert significant antihypertensive effects in clinical and preclinical studies [12]. This demonstrates the significance and prospect of finding active ACE inhibitory peptides from healthy foods.

Gracilariopsis lemaneiformis is a red algae that is widely distributed in the marine environment and has important economic value [13]. Gracilariopsis lemaneiformis belongs to the family Gracilariopsisceae (Rhodophyta), in which a majority of the members are utilized as the main sources of the manufacture of agar [14]. Gracilariopsis lemaneiformis is rich in polysaccharides, protein, vitamins, and multiple minerals such as phosphorus, calcium, iodine, iron, zinc and magnesium [15]. Polysaccharides, phycoerythrin, agar and other active substances isolated from G. lemaneiformis have proven to show a range of biological activities such as antioxidation, antitumor, immune regulation and alcoholic liver injury protection [16-19]. There are few studies, however, investigating active peptides of G. lemaneiformis, particularly ACE inhibitory peptides. To date, ACE inhibitory peptides have been extracted from various types of marine algae, such as Saccharina longicruris [20], Palmaria palmate [21], Pyropia columbina [22], Enteromorpha clathrata [23], Ulva rigida C. [24], Chlorella vulgaris [25], and Porphyra yezoensis [26]. This demonstrates that marine algae are an important source of active peptides.

In this study, ACE inhibitory peptides were screened from G. lemaneiformis enzymatic hydrolyte. By searching the online database, the physicochemical properties of the peptides were investigated. The stabilities of such peptides against $\mathrm{pH}$, temperature, gastrointestinal digestion and ACE hydrolysis were then assessed. Molecular docking was used to simulate the intermolecular interactions of peptides with ACE. Finally, the antihypertensive activities of the peptides were tested in vivo in spontaneously hypertensive rats (SHRs). 


\section{Results}

\subsection{Screening of the Active ACE Inhibitory Peptides.}

Two ACE inhibitory peptides were screened and identified by LC-MS/MS; the sequences are FQIN [M(O)] CILR and TGAPCR. The result shows that the peptides are two novel ACE inhibitors with the IC50 value of $9.64 \pm 0.36 \mu \mathrm{M}$ and $23.94 \pm 0.82 \mu \mathrm{M}$, respectively.

\subsection{Properties of Peptides}

The physicochemical properties of the peptide were obtained by online database search. Table 1 shows that the isoelectric points (PI) of FQIN [M(O)] CILR and TGAPCR are 8.61 and 8.55, respectively. Both peptides are non-toxic and can be used for animal studies. FQIN $[\mathrm{M}(\mathrm{O})]$ CILR has poor water solubility.

Table 1. Physicochemical characteristics of the two peptides.

\begin{tabular}{cccccc}
\hline Peptides & $\begin{array}{c}\text { Number of } \\
\text { Residues }\end{array}$ & $\begin{array}{c}\text { Molecular } \\
\text { Weight (Da) }\end{array}$ & ToxiPed & $\begin{array}{c}\text { Solubility in } \\
\text { Water }\end{array}$ & $\begin{array}{c}\text { Iso-Electric } \\
\text { Point (PI) }\end{array}$ \\
\hline FQIN [M(O)] CILR & 9 & 1153.43 & non-toxin & poor & 8.61 \\
TGAPCR & 6 & 603.69 & non-toxin & good & 8.55 \\
\hline
\end{tabular}

\subsection{Stability Study for ACE Inhibitory Activity}

The $\mathrm{pH}$ and thermal stability of the peptides were measured. The results show that the peptides could maintain their ACE inhibitory activity after $\mathrm{pH}$ and heat treatment (Figure $1 \mathrm{a}, \mathrm{b}$ ). Both peptides show $\mathrm{pH}$ and thermal stability.

The stability of the peptides in the simulated gastric juice and intestinal fluid is shown in Figure 2. After digestion in simulated gastric juice and intestinal fluid containing the corresponding enzymes, the ACE inhibitory activity of the peptides did not display any significant changes. The results demonstrate that these peptides have gastrointestinal stability, and they may also produce antihypertensive effects in vivo.

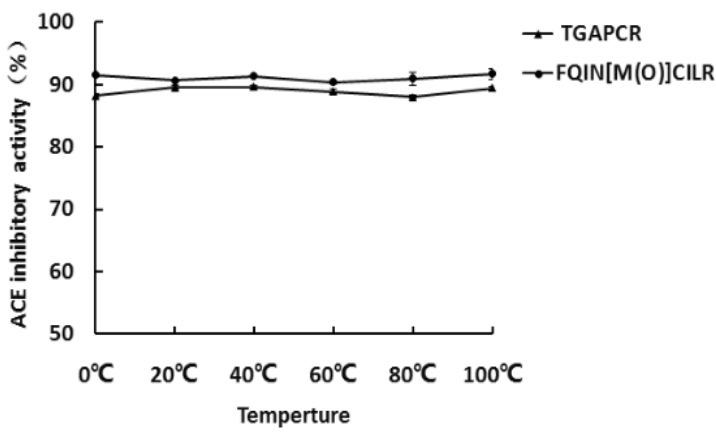

(a)

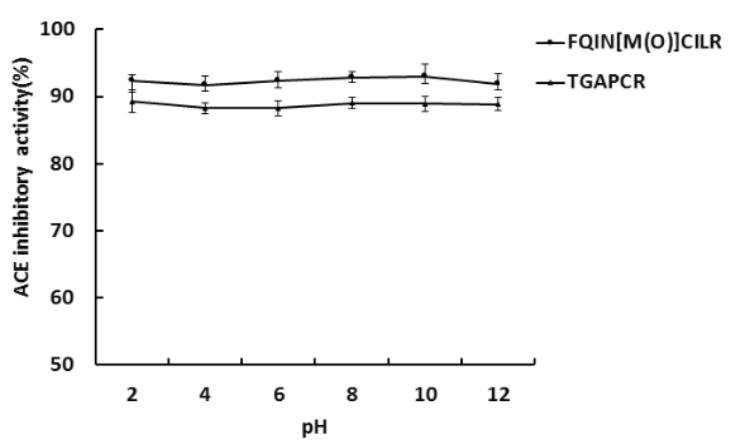

(b)

Figure 1. Temperature (a) and $\mathrm{pH}(\mathbf{b})$ stability of peptides FQIN $[\mathrm{M}(\mathrm{O})]$ CILR and TGAPCR. The concentration of peptides was $0.5 \mathrm{mg} / \mathrm{mL}$; values represent mean $\pm \operatorname{SD}(n=3)$. 


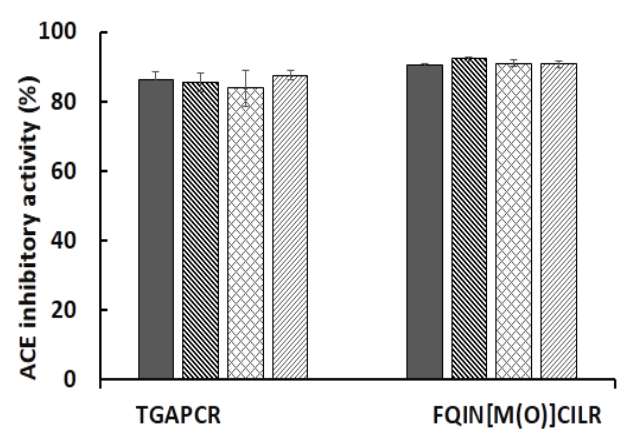

(a)

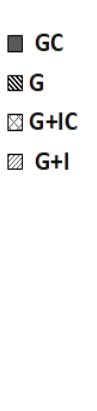

$\nabla G+I C$ G+I

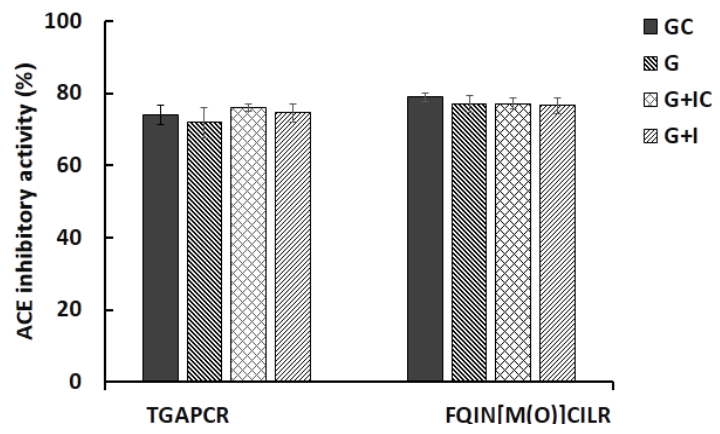

(b)

Figure 2. Stability of FQIN $[\mathrm{M}(\mathrm{O})]$ CILR and TGAPCR under simulated gastrointestinal digestion. The final concentrations of peptides were $0.5 \mathrm{mg} / \mathrm{mL}(\mathbf{a})$ and $0.1 \mathrm{mg} / \mathrm{mL}(\mathbf{b})$, respectively. GC, peptide sample and simulated gastric fluid without pepsin; G, peptide sample with gastric fluid with pepsin; G + IC, peptide sample and simulated gastrointestinal fluid without pepsin and pancreatin; $G+I$, peptide sample with gastrointestinal fluid with pepsin and pancreatin. Values represent mean \pm SD $(n=3)$.

\subsection{Stability of Peptides against $A C E$}

Figure 3 shows no significant changes of ACE inhibitory activity within incubation of ACE for $24 \mathrm{~h}$. The peptides maintained stable ACE inhibitory activity, suggesting that they were not hydrolyzed by ACE.

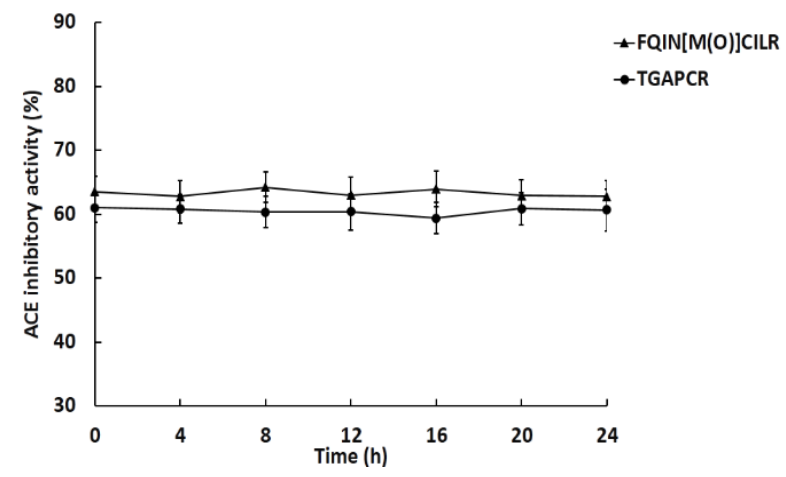

Figure 3. Stability of peptides against ACE. The concentration of peptides was $0.1 \mathrm{mg} / \mathrm{mL}$; values represent mean $\pm \mathrm{SD}(n=3)$.

\subsection{Characterization of the Inhibition Pattern on ACE}

Based on the results of the Lineweaver-Burk plots, both FQIN [M(O)] CILR and TGAPCR are noncompetitive inhibitors of ACE. Table 2 shows the kinetic parameters of the two peptides binding to ACE. Combined with the results shown in Figure 4, the value of $\mathrm{Km}(2.26 \pm 0.21 \mathrm{mM})$ is constant, which is an important characteristic of noncompetitive inhibition. In the noncompetitive inhibition pattern, the substrate and the inhibitory peptide bind to different parts of the enzyme. Thus, the apparent affinity of the substrate and the enzyme is a constant [27]. The Vmax $\left(2.23 \pm 0.67 \mathrm{mg}^{-1} \cdot \mathrm{mL} \cdot \mathrm{min}\right)$ decreases as the concentration of inhibitory peptide increases. This is due to the reduction of the apparent catalytic efficiency of ACE, which leads to the decrease of the enzymatic reaction efficiency [23]. At the same concentration, the Vmax of FQIN [M(O)] CILR is smaller than TGAPCR, indicating that FQIN $[\mathrm{M}(\mathrm{O})]$ CILR produce a better inhibitory activity than TGAPCR.

The Ki of FQIN $[\mathrm{M}(\mathrm{O})]$ CILR and TGAPCR are $0.71 \pm 0.04 \mathrm{mM}$ and $0.86 \pm 0.06 \mathrm{mM}$, respectively. The Ki value indicates the affinity of ACE inhibitory peptide to ACE. The lower the inhibition constant 
(Ki), the higher the affinity of the inhibitors to ACE. The results show that FQIN $[\mathrm{M}(\mathrm{O})]$ CILR can produce better inhibitory activity than TGAPCR.

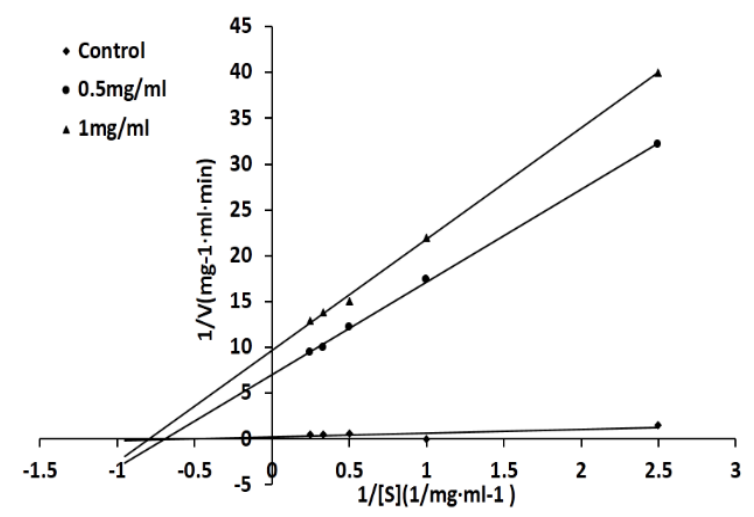

(a)

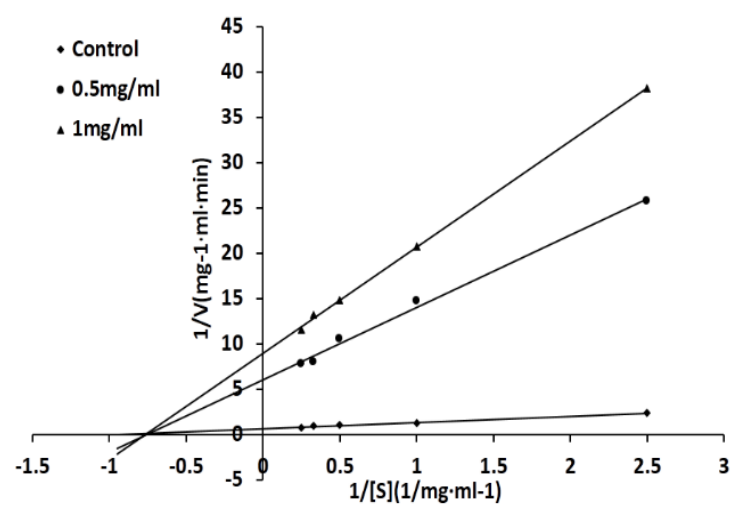

(b)

Figure 4. Lineweaver-Burk plots of ACE inhibited by the peptides. $1 / \mathrm{V}$ and $1 / \mathrm{S}$ represents the reciprocal of reaction velocity and substrate concentration, respectively. (a) FQIN $[\mathrm{M}(\mathrm{O})]$ CILR; (b) TGAPCR.

Table 2. Kinetics parameters of ACE-catalyzed reactions in different peptide concentrations.

\begin{tabular}{|c|c|c|c|c|c|}
\hline \multirow{2}{*}{$\begin{array}{c}\text { Kinetics } \\
\text { Parameters }\end{array}$} & \multirow{2}{*}{ Control } & \multicolumn{2}{|c|}{ FQIN [M(O)] CILR } & \multicolumn{2}{|c|}{ TGAPCR } \\
\hline & & $1 \mathrm{mg} / \mathrm{mL}$ & $0.5 \mathrm{mg} / \mathrm{mL}$ & $1 \mathrm{mg} / \mathrm{mL}$ & $0.5 \mathrm{mg} / \mathrm{mL}$ \\
\hline $\mathrm{Km}(\mathrm{mM})$ & $2.66 \pm 0.21$ & \multicolumn{2}{|c|}{$2.66 \pm 0.21$} & \multicolumn{2}{|c|}{$2.66 \pm 021$} \\
\hline $\begin{array}{c}\mathrm{Vmax} \\
\left(\mathrm{mg}^{-1} \cdot \mathrm{mL} \cdot \min \right)\end{array}$ & $2.23 \pm 0.67$ & $0.10 \pm 0.05$ & $0.14 \pm 0.02$ & $0.11 \pm 0.03$ & $0.17 \pm 0.02$ \\
\hline $\mathrm{Ki}(\mathrm{mM})$ & & \multicolumn{2}{|c|}{$0.71 \pm 0.04$} & \multicolumn{2}{|c|}{$0.86 \pm 0.06$} \\
\hline
\end{tabular}

\subsection{Molecular Docking}

CDOCKER was used to discover the ligand-receptor interaction mechanism. The -CDOCKER ENERGY and -CDOCKER INTERACTION ENERGY of FQIN [M(O)] CILR are $158.117 \mathrm{kcal} \cdot \mathrm{mol}^{-1}$ and $105.509 \mathrm{kcal} \cdot \mathrm{mol}^{-1}$, respectively. The -CDOCKER ENERGY and -CDOCKER INTERACTION ENERGY of TGAPCR are $90.4226 \mathrm{kcal} \cdot \mathrm{mol}^{-1}$ and $105.509 \mathrm{kcal} \cdot \mathrm{mol}^{-1}$, respectively (Table 3). Both peptides have a stable docking structure with ACE. The 2D and 3D structures of the peptide-ACE complexes are displayed in Figure 5a-d.

There are three main active site pockets in the ACE molecule. S1 pocket has three residues, Ala354, Glu384, and Tyr523. S2 pocket comprises of Gln281, His353, Lys511, His513, and Tyr520. S1'pocket includes residue Glu162 [28,29]. Inhibitory peptides interact with the active pockets of ACE through a variety of forces: electrostatic forces, hydrogen bonds, van der Waals forces, and hydrophobic interactions (Figure $5 b, d$ ). Of these forces, hydrogen bonds play a major role. Table 4 shows that FQIN [M(O)] CILR forms twelve hydrogen bonds with ACE residues Asn277, Gln281, Lys511, Tyr523, Ser517, Ser516, Glu123, His353, Glu376. Specifically, FQIN [M(O)] CILR constructs one hydrogen bond with S1 pocket (Tyr523), four bonds with S2 pocket (His353, Lys511, Gln281, His353). TGAPCR forms seven hydrogen bonds with ACE residues Lys511, Gln281, Glu376, Glu384, His353, Tyr394, Arg402. Specifically, Lys511, Gln281 and His353 belong to S2 pocket, link with TGAPCR through three hydrogen bonds and Glu384 belongs to S1 pocket. We speculate that FQIN [M(O)] CILR has a lower IC50 than TGAPCR because FQIN [M(O)] CILR forms a tighter bond with ACE. 


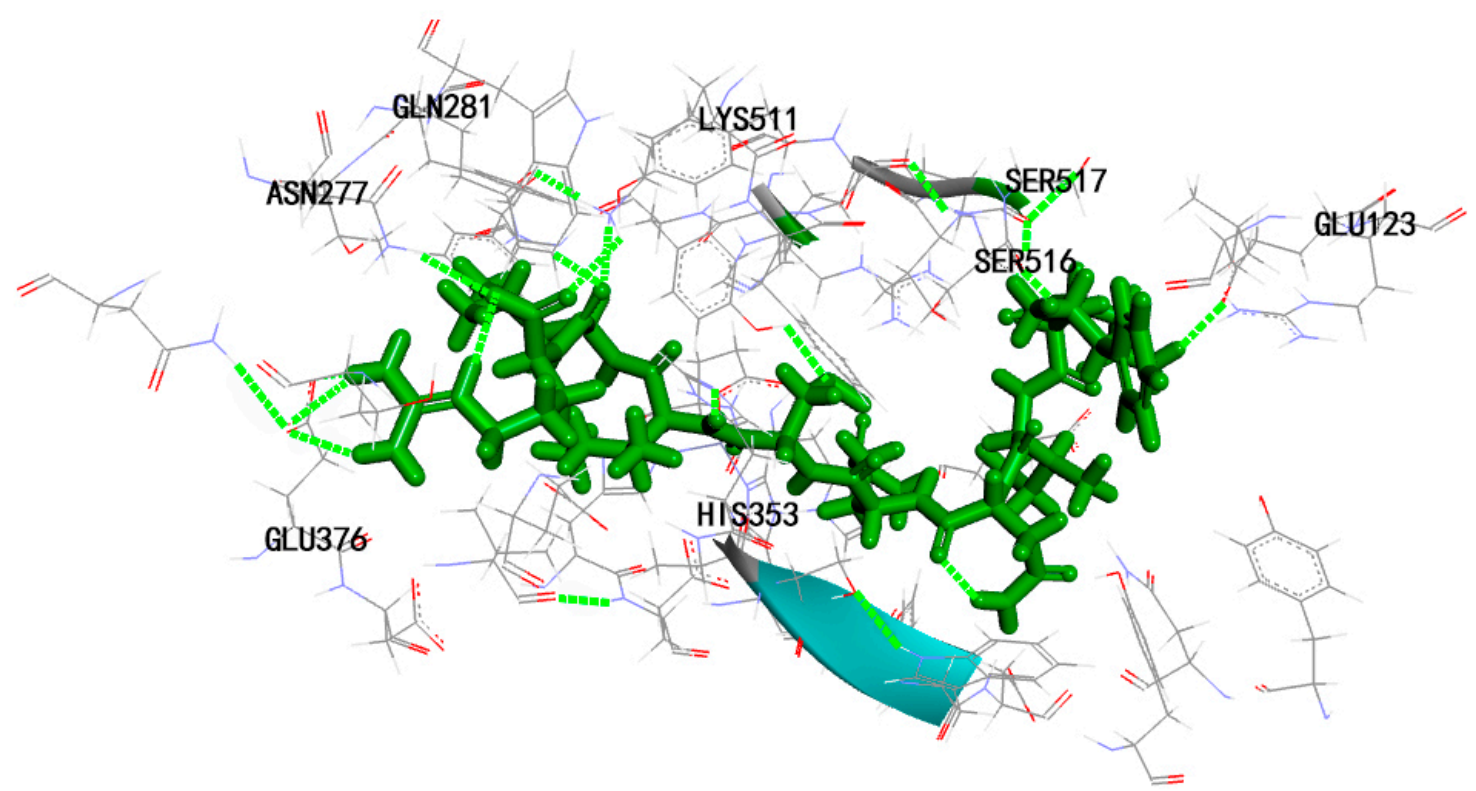

(a)

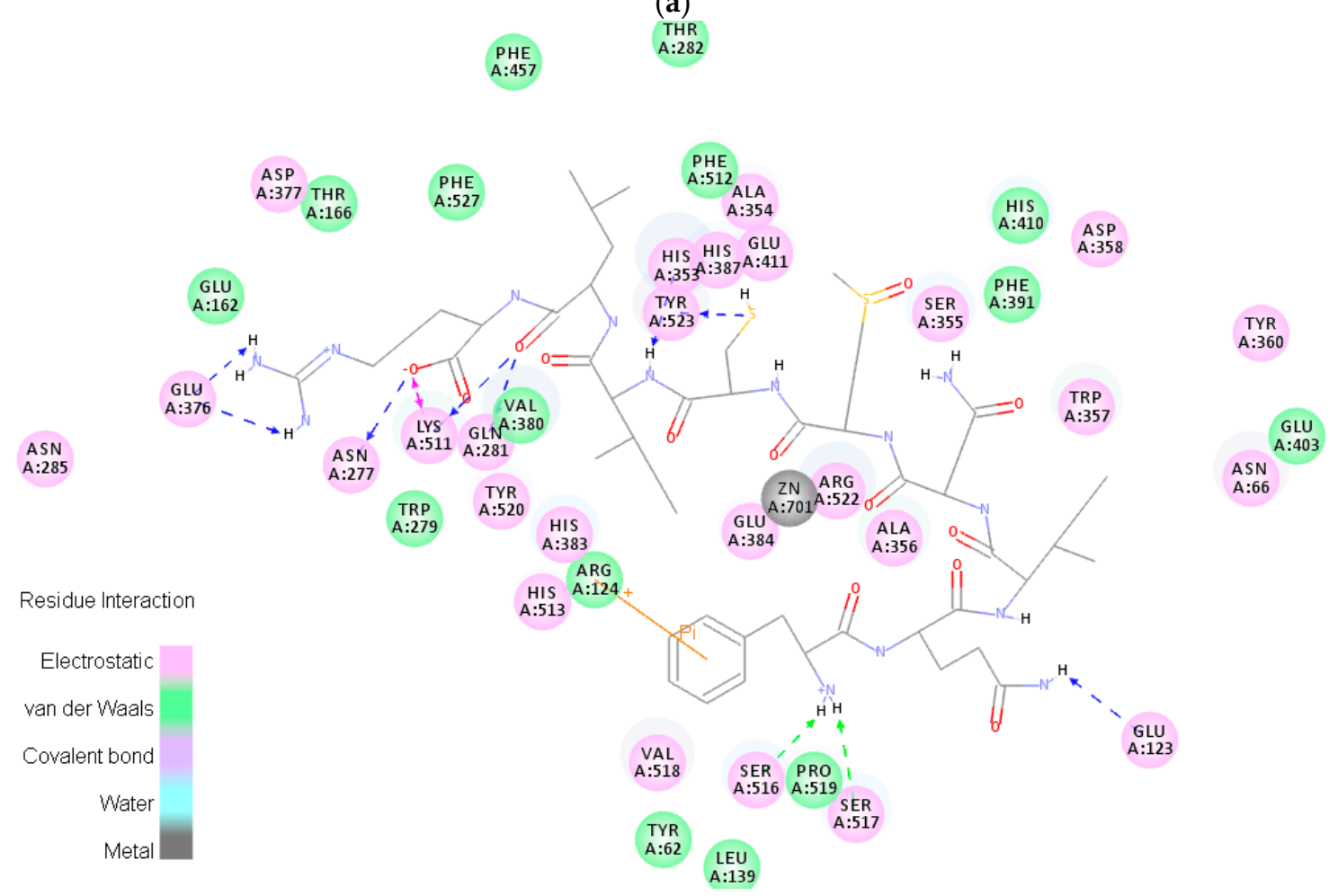

(b)

Figure 5. Cont. 


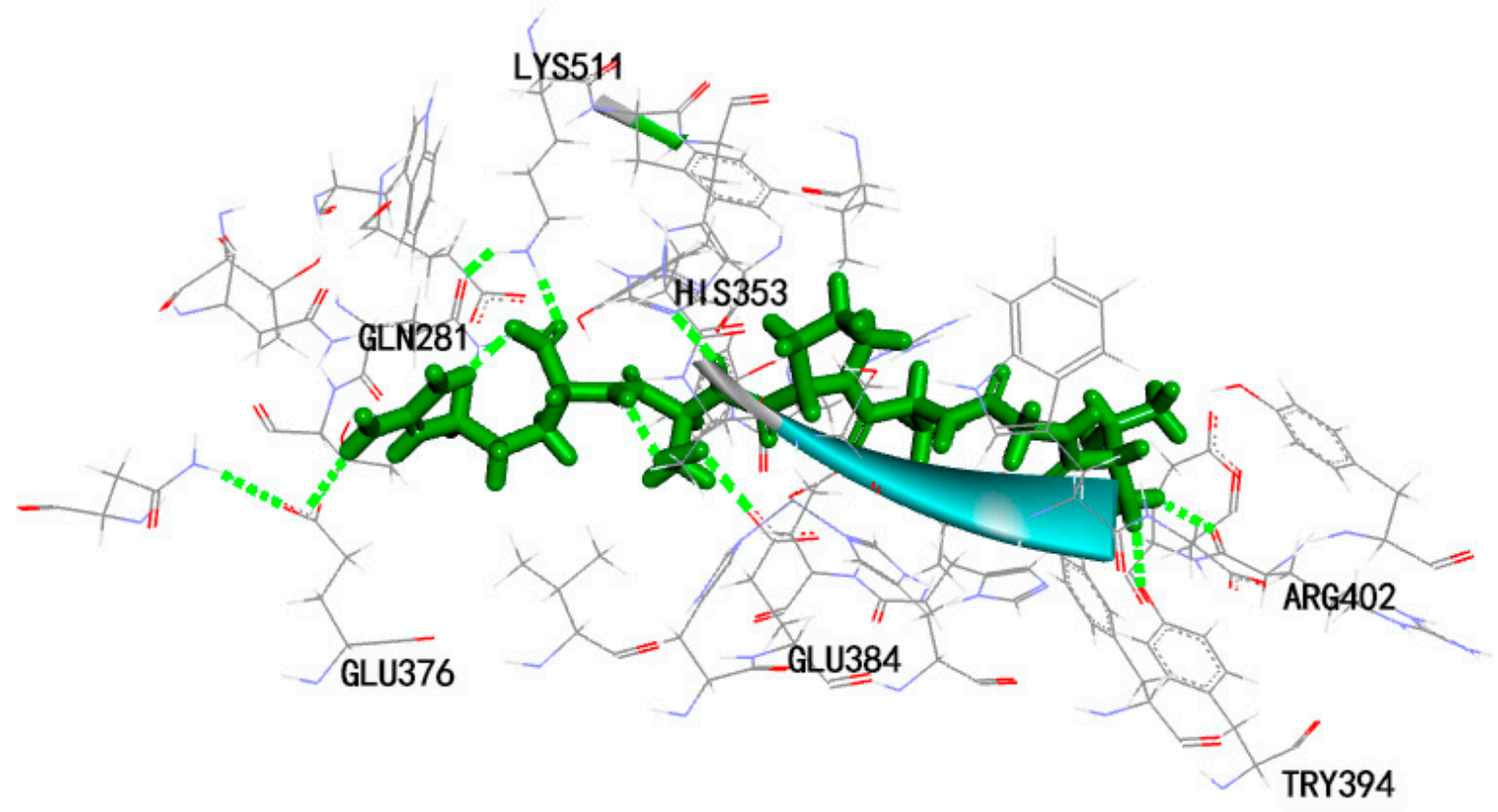

(c)

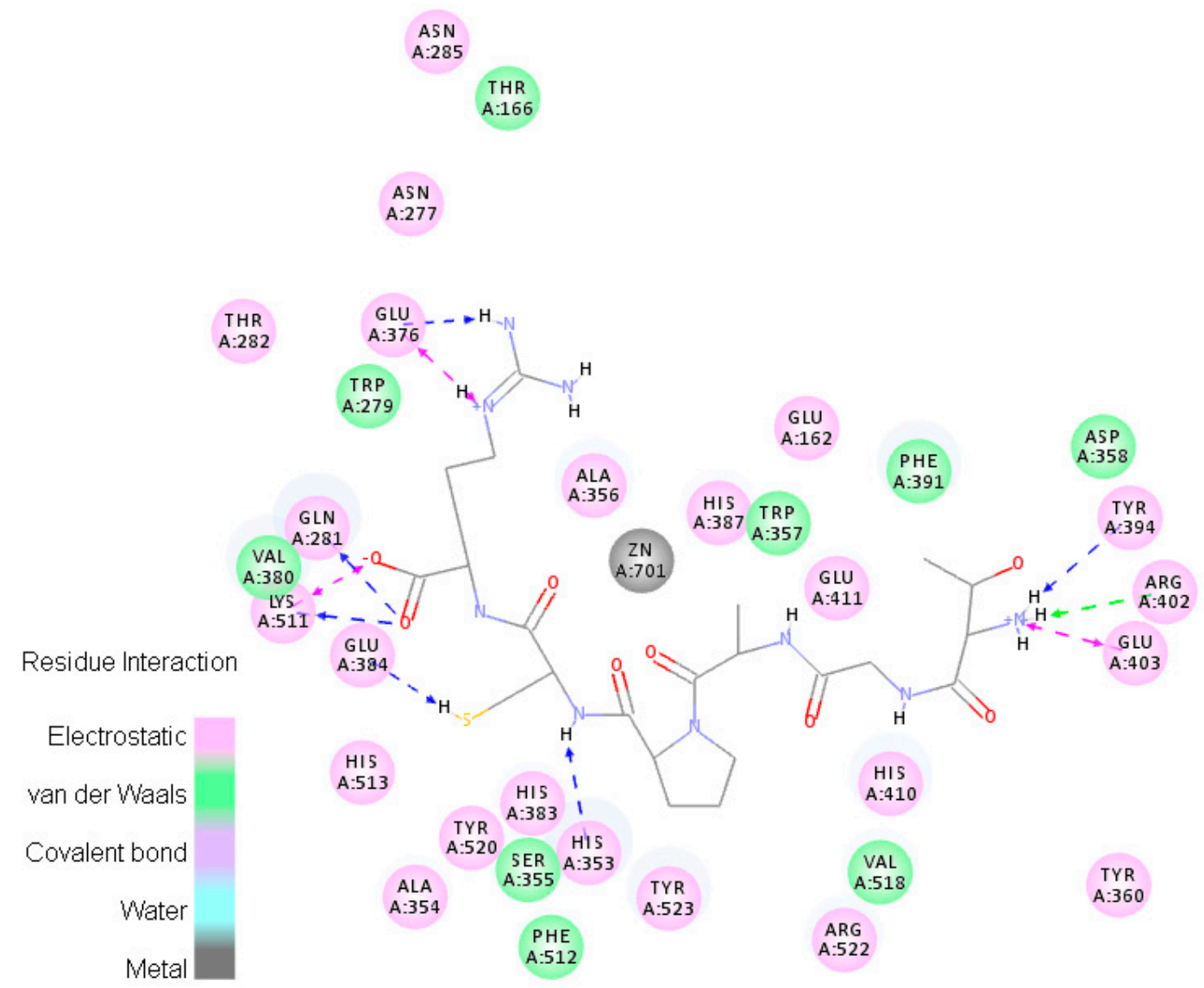

(d)

Figure 5. Molecular docking simulation of the peptides. (a,b) are local overview and two-dimensional (2D) diagram of FQIN [M(O)] CILR; (c,d) are local overview and two-dimensional (2D) diagram of TGAPCR. 
Table 3. Docking energies for optimal conformation of two ACE inhibit peptides and ACE.

\begin{tabular}{ccc}
\hline Peptides & $\begin{array}{c}\text {-CDOCKER ENERGY } \\
\left(\mathbf{k c a l} \cdot \mathbf{m o l}^{-\mathbf{1}} \mathbf{)}\right.\end{array}$ & $\begin{array}{c}\text {-CDOCKER INTERACTION } \\
\text { ENERGY (kcal·mol }^{-\mathbf{1}} \mathbf{)}\end{array}$ \\
\hline FQIN [M(O)] CILR & 158.117 & 145.01 \\
TGAPCR & 90.4226 & 105.509 \\
\hline
\end{tabular}

Table 4. Hydrogen bonds formed between two ACE inhibitory peptides and ACE.

\begin{tabular}{|c|c|c|c|c|}
\hline Peptides & Donor Atom & Acceptor Atom & Distance (Å) & Active Pocket \\
\hline \multirow{12}{*}{ FQIN $[\mathrm{M}(\mathrm{O})]$ CILR } & A: ASN277: HD22 & F: O125 & 2.39 & \\
\hline & A: GLN281: HE22 & F: O89 & 1.97 & S2 \\
\hline & A: LYS511: HZ1 & F: O89 & 2.02 & S2 \\
\hline & A: LYS511: HZ3 & F: O126 & 2.31 & S2 \\
\hline & A: TYR523: HH & F: S63 & 2.24 & S1 \\
\hline & F: H145 & A: SER517: O & 1.95 & \multirow{7}{*}{ S2 } \\
\hline & F: H146 & A: SER516: O & 1.98 & \\
\hline & F: H148 & A: GLU123: OE1 & 2.14 & \\
\hline & F: H158 & A: HIS353: NE2 & 2.33 & \\
\hline & F: H161 & A: GLU376: OE1 & 2.44 & \\
\hline & F: H161 & A: GLU: 376: OE2 & 2.03 & \\
\hline & F: H163 & A: GLU: 376: OE1 & 2.32 & \\
\hline \multirow{7}{*}{ TGAPCR } & A: GLN281: HE22 & $\mathrm{T}: \mathrm{O} 2$ & 2.06 & S2 \\
\hline & A: LYS511: HZ1 & $\mathrm{T}: \mathrm{O} 2$ & 1.78 & S2 \\
\hline & T: H71 & A: GLU376: OE2 & 2.16 & \\
\hline & T: H75 & A: GLU384: OE2 & 2.26 & S1 \\
\hline & T: H76 & A: HIS353: NE2 & 2.24 & S2 \\
\hline & T: H78 & A: TYR394: OH & 2.32 & \\
\hline & T: H79 & A: ARG402: O & 2.41 & \\
\hline
\end{tabular}

$\mathrm{F}$ is an abbreviation of FQIN [M(O)] CILR; $\mathrm{T}$ is an abbreviation of TGAPCR.

\subsection{Antihypertensive Activity of the Two Peptides on SHRs}

The in vivo antihypertensive activity of peptides was assessed by SHRs with a gavage dose of $10 \mathrm{mg} / \mathrm{mL}$. Both FQIN [M(O)] CILR and TGAPCR decreased the SBP of SHRs. FQIN [M(O)] CILR significantly decreased the SBP between 2 to $4 \mathrm{~h}(p<0.05)$, with the largest decrease of SBP from 204 to $170 \mathrm{mmHg}$ occurring at $2 \mathrm{~h}$. The SBP then began to recover and maintained a level of $200 \mathrm{mmHg}$ at $8 \mathrm{~h}$ (Figure 6a). It was notable that the FQIN [M(O)] CILR reduced the SBP of SHRs by $34 \mathrm{mmHg}$ to the maximum extent. TGAPCR reduced SBP to the lowest point at $2 \mathrm{~h}$. The greatest decline observed was approximately $28 \mathrm{mmHg}$ of SBP from $205 \mathrm{mmHg}$ to $178 \mathrm{mmHg}$.

In addition, both FQIN [M(O)] CILR and TGAPCR could also affect DBP (Figure 6b). FQIN [M(O)] CILR could significantly reduce the DBP of SHRs from $145 \mathrm{mmHg}$ to $118 \mathrm{mmHg}$ at $2 \mathrm{~h}(p<0.05)$, then restore to its original level at $8 \mathrm{~h}$. TGAPCR could decrease DPH to $120 \mathrm{mmHg}$ at $1 \mathrm{~h}$ and maintain the DPH until $4 \mathrm{~h}$. TGAPCR can maintain low DBP for a longer period of time compared to FQIN $[\mathrm{M}(\mathrm{O})] \mathrm{CILR}$. In general, FQIN $[\mathrm{M}(\mathrm{O})]$ CILR has a better antihypertensive effect in SHRs than TGAPCR. 


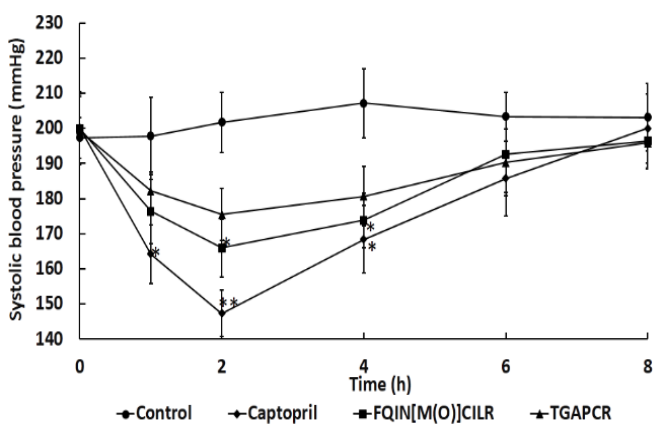

(a)

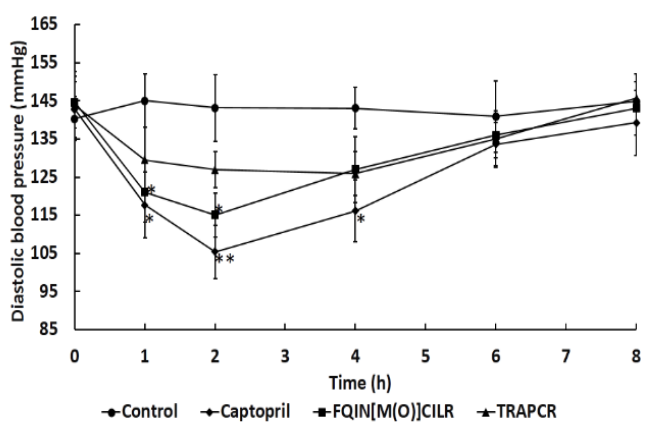

(b)

Figure 6. Changes of spontaneously hypertensive rats' systolic blood pressure (SBP) and diastolic blood pressure (DBP) after oral administration of the two peptides. Saline and Captopril were used as the control and positive control, respectively. Single oral administration was performed with a dose of $10 \mathrm{mg} / \mathrm{kg}$ body weight. Blood pressures were measured prior to and 1, 2, 4, 6, $8 \mathrm{~h}$ after oral administration. The difference with a value of $p<0.05$ was considered to be significant. (a) SBP changes;

(b) DBP changes.

\section{Discussion}

Natural products and derivate are considered relatively safe with limited side effects and thus will become an important source for clinical medications of hypertension in the future [30]. An increasing number of researchers have been investigating natural antihypertensive peptides, in which a variety of antihypertensive peptides with specific sequences and limited side effects have been extracted from animals and plants [10]. Algae accounts for 50\% of marine living resources. Thus, marine algae can be used as an important source for extracting active peptides. Researchers have extracted antihypertensive peptides from Saccharina longicruris [20], Palmaria palmate [21], Pyropia columbina [22], and other types of marine algae. However, there are few reports of extracting antihypertensive peptides from G. lemaneiformis. Here, we reported that two peptides extracted from G. lemaneiformis have the activity to inhibit ACE.

D.Q. Cao et al. have reported that a peptide (QVEY, IC50 = 474.36 $\mu \mathrm{M}$ ) isolated from trypsin hydrolyzate of $G$. lemaneiformis had ACE inhibitory activity [31]. FQIN [M(O)] CILR $(\mathrm{IC} 50=9.64 \pm 0.36 \mu \mathrm{M})$ and TGAPCR $(\mathrm{IC} 50=23.94 \pm 0.82 \mu \mathrm{M})$ were also screened from trypsin hydrolyzate of G. lemaneiformis, but the two peptides have lower IC50 values than the ACE inhibitory peptide reported above. The two peptides isolated from $G$. lemaneiformis showed higher activity than some reported C-terminal arginine ACE inhibitory peptides YIPIQYVLSR (IC50 = $132.5 \mu \mathrm{M})$, YASGR $(\mathrm{IC} 50=184 \mu \mathrm{M})$ and GNGSGYVSR $($ IC50 = $29 \mu \mathrm{M})[32,33]$. According to earlier studies, C-terminal arginine plays an important role in inhibiting the activity of ACE. The interaction between C-terminal arginine and ACE can be further analyzed in the molecular docking results.

The properties and stabilities of peptides are prerequisites for the preparation of "functional peptides". According to the information in the Innovagen server, FQIN [M(O)] CILR has poor water solubility. However, in our study, we found that the FQIN [M(O)] CILR had good water solubility when the concentration was lower than $10 \mathrm{mg} / \mathrm{mL}$. The solubility gradually decreased when the concentration was above $10 \mathrm{mg} / \mathrm{mL}$. The hydrophobicity of FQIN [M(O)] CILR is related to the presence of hydrophobic amino acids, such as Phe, Leu, Ile, and Met. The hydrophobicity of FQIN $[\mathrm{M}(\mathrm{O})]$ CILR may facilitate the binding of peptides to the hydrophobic active center of ACE, in turn, produce better inhibitory activity.

Small molecule peptides can cross the intestinal wall and enter the blood circulation. Prior to this, peptides must resist the gastrointestinal digestion and maintain their integrity, otherwise their biological activity may be activated or inactivated [34]. Our results suggested that the peptides can maintain the inhibitory activity after being absorbed into the blood. 
Angiotensin I-converting enzyme is a carboxypeptidase with very broad substrate specificity [35]. Some ACE inhibitory peptides may become substrates of ACE, which are cleaved into smaller fragments. As a result, the activity of the peptides is altered [34]. For example, ACE hydrolyzed FFGRCVSP isolated from dried bonito to four fragments FF, GR, GV, SP, while the IC50 value increased from $0.4 \mu \mathrm{M}$ to $4.6 \mu \mathrm{M}$ [7]. LKPNM (IC50 $=2.4 \mu \mathrm{M}$ ) isolated from dried bonito was hydrolyzed into LKP and NM, and the IC50 value of LKPNM became 1/3 after the pre-incubation with ACE [7]. In view of this, the stability of peptide binding to ACE must be taken into account. Our results proved that FQIN $[\mathrm{M}(\mathrm{O})]$ CILR and TGAPCR are stable ACE inhibitors but not substrates of ACE.

There are multiple inhibition patterns of ACE inhibitory peptides: competitive inhibition, noncompetitive inhibition, and mixed-competitive inhibition [36]. The results suggested that both peptides are noncompetitive inhibitors of ACE. Some peptides isolated from food stuffs have also been observed working in noncompetitive inhibition, for example, IFL from fermented soybean food [37], AVKVL from hazelnut [38], and VELWP from cuttlefish [39].

Molecular docking has become an important tool for elucidating the mechanisms of action between ligands and receptors [40]. The results of molecular docking suggested that the two peptides were linked to several pivotal amino acids that are important for ACE. His353, Ala354, and His513 were reported as important residues interacting with Lisinopril which formed six hydrogen bonds with ACE in the absence of the $\mathrm{H}_{2} \mathrm{O}$ molecule $[3,28,41]$. FQIN [M(O)] CILR and TGAPCR also formed hydrogen bonds with one of the three important residues (His353). Glu384 is the one formed coordination effect with $\mathrm{Zn}^{2+}$ [3]. Therefore, TGAPCR may also interfere ACE from combining with $\mathrm{Zn}^{2+}$, which in turn may contribute to ACE inhibitory activity. The results also highlighted the important role of arginine in the ACE inhibitory activity of the peptides [32]. The arginine of FQIN [M(O)] CILR formed five hydrogen bonds with the ACE residues Glu376, Asn277, Lys511. ACE residues Glu376, Lys511 and Gln281 formed three hydrogen bonds with the arginine of TGAPCR. Arginine enabled the peptides to form a tight bond with ACE, which facilitated the peptides' inhibitory activity against ACE.

Antihypertensive activity of peptides were further evaluated using spontaneously hypertensive rats (SHRs). The results indicated that captopril resulted in maximal antihypertensive effect on SHRs. Overall, drugs can exert better antihypertensive effects than hydrolysates and antihypertensive peptides derived from foods [2,42]. This may be because antihypertensive drugs have a more stable conformation and a more stringent structure. Both FQIN [M(O)] CILR and TGAPCR decreased the SBP of SHRs. FQIN [M(O)] CILR and TGAPCR reduced the SBP of SHRs by $34 \mathrm{mmHg}$ and $28 \mathrm{mmHg}$ to the maximum extent, respectively. FQIN [M(O)] CILR also decreased the DBP of SHRs significantly $(p<0.05)$. HLFGPPGKKDPV (IC50 $=125 \mu \mathrm{M})$, separated from fertilized eggs, had the greatest SBP drop of $30 \mathrm{mmHg}$, following an oral dose of $10 \mathrm{mg} / \mathrm{kg}$ [43]. QPGPT (IC50 = $80.67 \mu \mathrm{M}$ ) and GDIGY (IC50 $=32.56 \mu \mathrm{M}$ ), isolated from jellyfish, reduced the SBP by $13.75 \mathrm{mmHg}$ and $20.67 \mathrm{mmHg}$, respectively [44]. In comparison to the aforementioned peptides, FQIN [M(O)] CILR (IC50 $=9.64 \pm 0.36 \mu \mathrm{M})$ may have a strong antihypertensive effect, suggesting that it has considerable potential in the control of blood pressure.

FQIN $[\mathrm{M}(\mathrm{O})]$ CILR and TGAPCR are two novel ACE inhibitory peptides, isolated from the trypsin hydrolysate of G. lemaneiformis. The results demonstrated that FQIN [M(O)] CILR and TGAPCR not only showed strong ACE inhibitory activity in vitro but also showed strong antihypertensive effects in SHRs. This study suggested that these two natural peptides have the potential to be developed for both antihypertensive drugs and health care products.

\section{Materials and Methods}

\subsection{Chemicals}

ACE (from rabbit lung), hippuryl-histidyl-leucine (HHL), high-performance liquid chromatography (HPLC)-grade acetonitrile (ACN), trifluoroaceticacid (TFA) and porcine pancreatin $(8 \times \mathrm{USP})$ were purchased from Sigma-Aldrich Co. (St. Louis, MO, USA). Trypsin (EC 3.4.23.4, $\geq 250$. N.F.U/mg solid), 
pepsin (EC 3.4.23.1, $\geq 250 \mathrm{U} / \mathrm{mg}$ solid), and captopril (>99\% purity) were obtained from Solarbio (Beijing, China). All other chemical reagents were of analytical grade.

\subsection{Preparation of G. Lemaneiformis Hydrolysates}

G. lemaneiformis was hydrolyzed with $2 \%$ trypsin (EC 3.4.23.4, $\geq 250$. N. F. U./mg solid) for $2 \mathrm{~h}$. The $80 \%$ alcohol was used to precipitate the impurities in the hydrolysates. The supernatant was concentrated to remove ethanol. Next, the concentrated supernatant was fractionated by ultrafiltration (LNG-UF-101, Laungy Membrane Filtration Technology Co. Ltd., Shanghai, China) and the fraction $(<3 \mathrm{KDa})$ was collected and freeze-dried before storage at $-80{ }^{\circ} \mathrm{C}$.

\subsection{Identification of Peptides by LC-MS/MS}

Peptide sequences were determined according to Kai Lin [45]. Identification of peptides in 3 KDa permeates was performed using a Q-Exactive mass spectrometer (Thermo Fisher Scientific, Waltham, MA, USA) coupled with a Thermo Scientific EASY-nLC 1000 System (Thermo Fisher Scientific, Waltham, MA, USA). Samples were loaded in a reverse-phase trap column $(2 \mathrm{~cm} \times 100 \mu \mathrm{m}, 5 \mu \mathrm{m}-\mathrm{C} 18)$, which was connected to a reverse-phase analytical column $(75 \mu \mathrm{m} \times 100 \mu \mathrm{m}, 3 \mu \mathrm{m}$-C18). The purified sample was injected into the trapping column at a flow rate of $300 \mathrm{~nL} / \mathrm{min}$. The mass spectrometer (MS) was operated in positive-ion detection mode, and the most abundant precursor ions from the scanning range of 300-1800 $\mathrm{m} / \mathrm{z}$ were selected to obtain MS data. Peptide sequences were determined based on the MS/MS spectra and Mascot 2.2 (Matrix Science Inc., Boston, MA, USA) searches of dataset of G. lemaneiformis (Accession: SRX258772, download from SRA database of NCBI).

\subsection{Synthesis of ACE Inhibitory Peptides}

The inhibitory peptides were chemically synthesized in Shanghai Qiangyao Biotechnology Co., Ltd. (Shanghai, China). The peptides were synthesized using the Fmoc solid-phase method. To increase the stability of FQINMCILR, Methionine is selectively modified to methionine sulfoxide (FQIN $[M(O)]$ CILR). The purity of the two peptides is $97.85 \%$ and $97.59 \%$.

\subsection{Measurement of ACE Inhibition Activity}

ACE inhibition activity was assayed according to Cushman and Cheung, with some modification [27]. ACE was dissolved in sodium borate buffer ( $\mathrm{pH} 8.3$, containing $0.3 \mathrm{M}$ sodium chloride) to $0.1 \mathrm{U} / \mathrm{mL}$ for the assay. Synthetic peptides were dissolved in distilled water to seven concentration levels. Then, $20 \mu \mathrm{L}$ of a certain concentration of peptide was mixed with $10 \mu \mathrm{L}$ ACE solution. The mixture was incubated at $37^{\circ} \mathrm{C}$ for $5 \mathrm{~min}$, and then $50 \mu \mathrm{L}$ of $5 \mathrm{mM}$ HHL (sodium borate buffer $\mathrm{pH} 8.3$, containing $0.3 \mathrm{M}$ sodium chloride) was added to the above mixture to start the reaction. The reaction was maintained at $37^{\circ} \mathrm{C}$ for $60 \mathrm{~min}$, and then $150 \mu \mathrm{L}$ of $1 \mathrm{M} \mathrm{HCl}$ was added to stop the reaction. The solution was filtered through a 0.22 micron membrane. Next, $20 \mu \mathrm{L}$ of reaction solution was injected into a RP-HPLC (Shimadzu, Kyoto, Japan) fixed with Eclipse XDB-C18 column (4.6 mm $\times 150 \mathrm{~mm} \times 5 \mu \mathrm{m}$, Agilent Technologies Inc., St. Clara, CA, USA) to measure the concentration of hippuric acid (HA). The absorbance was detected at $228 \mathrm{~nm}$. All determinations were triplicate. The activity of ACE inhibition was calculated as followed:

$$
\text { ACE inhibitory activity }(\%)=\left(\mathrm{A}_{\text {control }}-\mathrm{A}_{\text {inhibitor }}\right) / \mathrm{A}_{\text {control }} \times 100
$$

where $\mathrm{A}_{\text {inhibitor }}$ is the relative area of the hippuric acid (HA) peak obtained from the reaction of ACE and HHL with inhibitor. $\mathrm{A}_{\text {control }}$ is the relative area of the hippuric acid (HA) peak obtained from the reaction of ACE and HHL without inhibitor. IC50 is defined as the concentration of peptides that can inhibit half of the ACE activity. 


\subsection{Properties of Peptides}

The properties of ACE inhibitory peptides are important for future research. These parameters can be retrieved from the online database. The ToxinPred server can analyze toxicity of the peptides (http://crdd.osdd.net/raghava/toxinpred/). The online Innovagen server was used to evaluate the solubility of the peptide (www.innovagen.com/proteomics-tools).

\subsection{Stability Study for ACE Inhibitory Activity}

\subsubsection{Thermal Stability for Peptides}

The synthetic peptide solutions $(0.5 \mathrm{mg} / \mathrm{mL})$ were incubated at different temperatures $\left(0{ }^{\circ} \mathrm{C}\right.$, $20^{\circ} \mathrm{C}, 40^{\circ} \mathrm{C}, 60^{\circ} \mathrm{C}, 80^{\circ} \mathrm{C}, 100^{\circ} \mathrm{C}$ ) for $2 \mathrm{~h}$. Next, $20 \mu \mathrm{L}$ of peptide was used to assay the ACE inhibitory activity using the above method [39].

\subsection{2. $\mathrm{pH}$ Stability for Peptides}

The synthetic peptide solutions $(0.5 \mathrm{mg} / \mathrm{mL})$ were incubated at different $\mathrm{pH}$ levels $(2,4,6,8,10$, 12) for $2 \mathrm{~h}$, and then solutions were neutralized to $\mathrm{pH} 7.0$ [39]. Then, $20 \mu \mathrm{L}$ of peptide was used to assay the ACE inhibitory activity using the above method.

\subsubsection{Gastrointestinal Stability of Peptides}

Gastrointestinal stability of peptides was evaluated in vitro [46,47]. Peptides were dissolved in a $0.1 \mathrm{M} \mathrm{KCl}-\mathrm{HCl}$ buffer (pH 2.0) to the concentration of $0.1 \mathrm{mg} / \mathrm{mL}$ and $0.5 \mathrm{mg} / \mathrm{mL}$. Pepsin $(\geq 250 \mathrm{U} / \mathrm{mg})$ was added to a peptide solution to the final concentration $0.8 \mathrm{mg} / \mathrm{mL}$. The solution was then incubated at $37^{\circ} \mathrm{C}$ for $4 \mathrm{~h}$. The pepsin was inactivated through boiling the solution for $10 \mathrm{~min}$. The $\mathrm{pH}$ of the solution was adjusted to 7.0 with $1 \mathrm{M} \mathrm{NaOH}$. The solution was centrifuged at 12,000 rpm for $5 \mathrm{~min}$ and the supernatant $(20 \mu \mathrm{L})$ was taken out to determine the ACE inhibitory activity. The remaining supernatant was further incubated with pancreatin $(10 \mathrm{mg} / \mathrm{mL}, 8 \times \mathrm{USP})$ at $37^{\circ} \mathrm{C}$ for $4 \mathrm{~h}$. The reaction was stopped by boiling the solution for $10 \mathrm{~min}$. The solution was centrifuged at 12,000 rpm for $10 \mathrm{~min}$, and then the supernatant $(20 \mu \mathrm{L})$ was used to detect ACE inhibitory activity.

\subsection{Stability of Peptides against ACE}

The stability of peptides against ACE was assayed according to Salampessy. J and Fujita. H [48,49]. $30 \mu \mathrm{L}$ of peptides $(0.1 \mathrm{mg} / \mathrm{mL})$ reacted with $30 \mu \mathrm{L} 0.1 \mathrm{U} / \mathrm{mL}$ ACE solution at $37^{\circ} \mathrm{C}$ for $24 \mathrm{~h}$. The ACE was then inactivated through boiling the solution for $10 \mathrm{~min}$. Then, $20 \mu \mathrm{L}$ of peptides were used to detect ACE inhibitory activity in the above method.

\subsection{Determination of Inhibitory Pattern}

Peptides were dissolved in distilled water to the concentration of $1 \mathrm{mg} / \mathrm{mL}$ and $0.5 \mathrm{mg} / \mathrm{mL}$, and HHL was dissolved to the concentration of $4 \mathrm{mg} / \mathrm{mL}, 2 \mathrm{mg} / \mathrm{mL}, 1 \mathrm{mg} / \mathrm{mL}$ and $0.5 \mathrm{mg} / \mathrm{mL}$. Different concentrations of the peptide were reacted at different concentrations of HHL. Then, $20 \mu \mathrm{L}$ of peptide solution was used to determine the ACE inhibitory activity using the above method. Lineweaver-Burk plots were applied to confirm the ACE inhibitory pattern of peptide. The inhibitory constant $(\mathrm{Ki})$ was the intercept of the $X$-axis of the plot, of which the $Y$-axis displayed the slopes of Lineweaver-Burk line and the $X$-axis indicted peptides concentrations [25].

\subsection{Molecular Docking}

The affinity of peptides to inhibit ACE was simulated and evaluated by Discovery Studio 3.5 (DS 3.5, Accelrys, San Diego, CA, USA), according to the reported method with some modification [32]. In the docking experiments, the crystal structure of human tACE (PDB ID: 1O8A, http: / / www.rcsb. $\mathrm{org} / \mathrm{pdb} /$ explore/ explore.do?structureId=1O8A) was as receptor. The 3D structure of the peptides 
was designed by Discovery Studio 3.5 (DS 3.5, Accelrys, San Diego, CA, USA). Then the peptide was protonated at $\mathrm{pH} 7.0$ and energetically minimized by the CHARMm force field. The structure of ACE was removed water, cleaned protein and added hydrogen. The CDOCKER was selected to simulate the docking of receptors and peptide ligands. The binding site sphere was $x: 40.302, y: 37.243$ and $z$ : 48.948. Rigid residues were residues within the sphere with a $20 \AA$ radius and with zinc as the center. CDOCKER module uses a CHARMm-based molecular dynamics (MD) scheme to dock ligands into a receptor binding site. Random ligand conformations are generated using high-temperature MD. The conformations are then translated into the binding site. Candidate poses are then created using random rigid-body rotations followed by simulated annealing. A final minimization is used to refine the ligand poses. -CDOCKER ENERGY and -CDCKER INTERACTION ENERGY are two criteria for evaluating CDOCKER results. -CDOCKER ENERGY indicates the negative of the total energy. -CDOCKER INTERACTION ENERGY indicates the negative of the interaction energy. The optimal conformation of peptide-ACE complex has the highest values of -CDOCKER ENERGY and-CDOCKER INTERACTION ENERGY.

\subsection{Antihypertensive Effect on SHRs}

Spontaneously hypertensive rats (SHRs) (male, 10-week-old, 250-300 g body weight, specific, pathogen-free) were bought from Vital River Laboratory Animal Co., Ltd. (Beijing, China). Animals used in this study were maintained in accordance with the guidelines of the Institutional Research Council's Guide for the Care and Use of Laboratory Animals. SHRs were housed under $12 \mathrm{~h}$ day $/ \mathrm{night}$ cycle at $22 \pm 2{ }^{\circ} \mathrm{C}$ and fed with tap water and a standard diet ad libitum. The SHRs were randomly separated into a positive group, control group, and two experiment groups. There were six SHRs in each group. Before the formal start of the test, SHRs had to adapt to measuring the environment in advance. Once the tail systolic blood pressure (SBP) rates were above $180 \mathrm{mmHg}$, the gavage administration could start.

Normal saline was the solvent to dissolve peptides and control reagent. Captopril (99\% purity, Solarbio Technology Co., Ltd., Beijing, China) was the positive group. The same volume of normal saline was the control group. Tail-cuff method was performed for systolic blood pressure (SBP) and diastolic blood pressure (DBP) measurements with a non-invasive CODA device (Kent Scientific Co., Torrington, CT, USA). The blood pressure was measured in $0,1,2,4,6,8 \mathrm{~h}$ after gavage administration. Measurements were repeated three times at each time point.

\subsection{Statistical Analysis}

Data analysis was performed using SPSS Version 17.0 (SPSS Inc., Chicago, IL, USA). To compare the mean differences among the groups, one-way analysis of variance was used. The results are shown as the mean $\pm \mathrm{SD}$, and $p<0.05$ was considered to be statistically significant.

\section{Conclusions}

Two ACE inhibitory peptides, identified as FQIN [M(O)] CILR and TGAPCR from G. lemaneiformis, inhibit ACE in a noncompetitive pattern. Molecular docking results showed that the peptides were mainly linked to ACE via hydrogen bonds and produce inhibitory activity. Animal experiment has shown that FQIN $[\mathrm{M}(\mathrm{O})]$ CILR and TGAPCR can reduce blood pressure of SHRs. Therefore, these peptides have the potential to treat hypertension, while G. lemaneiformis can be developed as an antihypertensive food.

Author Contributions: Z.D. conceived, designed, and performed the experiments; Y.L. performed the experiments; J.W., S.W. and L.G. analyzed the data; Q.Z. conceive the experiments.

Funding: This research was funded by the Fujian STS project of Chinese Academy of Sciences, the Science and Technology project of Fujian Province (No. 2017T3015, 2017T3013), the Key Research and Development Project of Shandong Province (grant number 2016YYSP002), the Youth Innovation Promotion Association of CAS (grant number 2016190) and K.C. Wong Education Foundation, CAS. 
Acknowledgments: We thank Elservier (https://www.elsevier.com/) for its linguistic assistance during the preparation of this manuscript. We thanks professor Zhenghong Sui provided us with the database. Finally, I am grateful to my teacher Quanbin Zhang for his guidance and support for my work.

Conflicts of Interest: The authors declare no conflict of interest.

\section{References}

1. Cornélissen, G.; Delcourt, A.; Toussaint, G.; Otsuka, K.; Watanabe, Y.; Siegelova, J.; Fiser, B.; Dusek, J.; Homolka, P.; Singh, R.B.; et al. Opportunity of detecting pre-hypertension: worldwide data on blood pressure overswinging. Biomed. Pharmacother. 2005, 59, S152-S157. [CrossRef]

2. Faria, M.; Costa, E.L.; Gontijo, J.A.; Netto, F.M. Evaluation of the hypotensive potential of bovine and porcine collagen hydrolysates. J. Méd. Food 2008, 11, 560-567. [CrossRef] [PubMed]

3. Natesh, R.; Schwager, S.L.U.; Sturrock, E.D.; Acharya, K.R. Crystal structure of the human angiotensin-converting enzyme-lisinopril complex. Nature 2003, 421, 551. [CrossRef] [PubMed]

4. Pacurari, M.; Kafoury, R.; Tchounwou, P.B.; Ndebele, K. The Renin-Angiotensin-aldosterone system in vascular inflammation and remodeling. Int. J. Inflamm. 2014, 2014, 689360. [CrossRef] [PubMed]

5. Chen, C.C.; Ke, W.H.; Ceng, L.H.; Hsieh, C.W.; Wung, B.S. Calcium- and phosphatidylinositol 3-kinase/Akt-dependent activation of endothelial nitric oxide synthase by apigenin. Life Sci. 2010, 87, 743-749. [CrossRef] [PubMed]

6. Martin, J.; Hartl, F.U. Molecular chaperones in cellular protein folding. Bioessays 1994, 16, 689-692. [CrossRef] [PubMed]

7. Fujita, H.; Yokoyama, K.; Yoshikawa, M. Classification and antihypertensive activity of angiotensin I-converting enzyme inhibitory peptides derived from food proteins. J. Food Sci. 2000, 65, 564-569.

8. Alemán, A.; Giménez, B.; Pérez-Santin, E.; Gómez-Guillén, M.C.; Montero, P. Contribution of Leu and Hyp residues to antioxidant and ACE-inhibitory activities of peptide sequences isolated from squid gelatin hydrolysate. Food Chem. 2011, 125, 334-341. [CrossRef]

9. García-Mora, P.; Martín-Martinez, M.; Bonache, M.A.; Gonzalez-Muniz, M.; Peñas, E.; Frias, J.; Martínez-Villaluenga, C. Identification, functional gastrointestinal stability and molecular docking studies of lentil peptides with dual antioxidant and angiotensin I converting enzyme inhibitory activities. Food Chem. 2017, 221, 464-472. [CrossRef] [PubMed]

10. Aluko, R.E. Structure and function of plant protein-derived antihypertensive peptides. Curr. Opin. Food Sci. 2015, 4, 44-50. [CrossRef]

11. Wijesekara, I.; Kim, S. Angiotensin-I-converting enzyme (ACE) inhibitors from marine resources: Prospects in the pharmaceutical industry. Mar. Drugs 2010, 8, 1080-1093. [CrossRef] [PubMed]

12. Aluko, R.E. Antihypertensive peptides from food proteins. Annu. Rev. Food Sci. Technol. 2015, 6, $235-262$. [CrossRef] [PubMed]

13. Chen, B.; Zou, D.; Zhu, M.; Yang, Y. Effects of $\mathrm{CO}_{2}$ levels and light intensities on growth and amino acid contents in red seaweed Gracilaria lemaneiformis. Aquac. Res. 2016, 48, 2683-2690. [CrossRef]

14. Fan, Y.; Wang, W.; Song, W.; Chen, H.; Teng, A.; Liu, A. Partial characterization and anti-tumor activity of an acidic polysaccharide from Gracilaria lemaneiformis. Carbohydr. Polym. 2012, 88, 1313-1318. [CrossRef]

15. Li, P.; Ying, J.; Chang, Q.; Zhu, W.; Yang, G.; Xu, T.; Yi, H.; Pan, R.; Zhang, E.; Zeng, X.; et al. Effects of phycoerythrin from Gracilaria lemaneiformis in proliferation and apoptosis of SW480 cells. Oncol. Rep. 2016, 36, 3536-3544. [CrossRef] [PubMed]

16. Jin, M.; Liu, H.; Hou, Y.; Chan, Z.; Di, W.; Li, L.; Zeng, R. Preparation, characterization and alcoholic liver injury protective effects of algal oligosaccharides from Gracilaria lemaneiformis. Food Res. Int. 2017, 100, 186-195. [CrossRef] [PubMed]

17. Ren, Y.; Zheng, G.; You, L.; Wen, L.; Li, C.; Fu, X.; Zhou, L. Structural characterization and macrophage immunomodulatory activity of a polysaccharide isolated from Gracilaria lemaneiformis. J. Funct. Foods 2017, 33, 286-296. [CrossRef]

18. Wen, L.; Zhang, Y.; Sun-Waterhouse, D.; You, L.; Fu, X. Advantages of the polysaccharides from Gracilaria lemaneiformis over metformin in antidiabetic effects on streptozotocin-induced diabetic mice. RSC Adv. 2017, 7, 9141-9151. [CrossRef] 
19. Yuan, S.; Duan, Z.; Lu, Y.; Ma, X.; Wang, S. Optimization of decolorization process in agar production from Gracilaria lemaneiformis and evaluation of antioxidant activities of the extract rich in natural pigments. Biotech. 2018, 8, 8. [CrossRef] [PubMed]

20. Beaulieu, L.; Bondu, S.; Doiron, K.; Rioux, L.; Turgeon, S.L. Characterization of antibacterial activity from protein hydrolysates of the macroalga Saccharina longicruris and identification of peptides implied in bioactivity. J. Funct. Foods 2015, 17, 685-697. [CrossRef]

21. Beaulieu, L.; Sirois, M.; Tamigneaux, É. Evaluation of the in vitro biological activity of protein hydrolysates of the edible red alga, Palmaria palmata (dulse) harvested from the Gaspe coast and cultivated in tanks. J. Appl. Phycol. 2016, 28, 3101-3115. [CrossRef]

22. Cian, R.E.; Garzón, A.G.; Ancona, D.B.; Guerrero, L.C.; Drago, S.R. Hydrolyzates from Pyropia columbina seaweed have antiplatelet aggregation, antioxidant and ACE I inhibitory peptides which maintain bioactivity after simulated gastrointestinal digestion. LWT Food Sci. Technol. 2015, 64, 881-888. [CrossRef]

23. Pan, S.; Wang, S.; Jing, L.; Yao, D. Purification and characterisation of a novel angiotensin-I converting enzyme (ACE)-inhibitory peptide derived from the enzymatic hydrolysate of Enteromorpha clathrata protein. Food Chem. 2016, 211, 423-430. [CrossRef] [PubMed]

24. Paiva, L.; Lima, E.; Neto, A.I.; Baptista, J. Isolation and characterization of angiotensin I-converting enzyme (ACE) inhibitory peptides from Ulva rigida C. Agardh protein hydrolysate. J. Funct. Foods 2016, 26, 65-76. [CrossRef]

25. Xie, J.; Chen, X.; Wu, J.; Zhang, Y.; Zhou, Y.; Zhang, L.; Tang, Y.; Wei, D. Antihypertensive Effects, Molecular Docking Study, and Isothermal Titration Calorimetry Assay of Angiotensin I-Converting Enzyme Inhibitory Peptides from Chlorella vulgaris. J. Agric. Food Chem. 2018, 66, 1359-1368. [CrossRef] [PubMed]

26. Qu, W.; Ma, H.; Li, W.; Pan, Z.; Owusu, J.; Venkitasamy, C. Performance of coupled enzymatic hydrolysis and membrane separation bioreactor for antihypertensive peptides production from Porphyra yezoensis protein. Process Biochem. 2015, 50, 245-252. [CrossRef]

27. Li, H.; Aluko, R.E. Kinetics of the inhibition of calcium/calmodulin-dependent protein kinase II by pea protein-derived peptides. J. Nutr. Biochem. 2005, 16, 656-662. [CrossRef] [PubMed]

28. Wu, Q.; Jia, J.; Yan, H.; Du, J.; Gui, Z. A novel angiotensin-capital I, Ukrainian converting enzyme (ACE) inhibitory peptide from gastrointestinal protease hydrolysate of silkworm pupa (Bombyx mori) protein: Biochemical characterization and molecular docking study. Peptides 2015, 68, 17-24. [CrossRef] [PubMed]

29. Rohit, A.C.; Sathisha, K.; Aparna, H.S. A variant peptide of buffalo colostrum beta-lactoglobulin inhibits angiotensin I-converting enzyme activity. Eur. J. Med. Chem. 2012, 53, 211-219. [CrossRef] [PubMed]

30. Furuta, T.; Miyabe, Y.; Yasui, H.; Kinoshita, Y.; Kishimura, H. Angiotensin I Converting Enzyme Inhibitory Peptides Derived from Phycobiliproteins of Dulse Palmaria palmata. Mar. Drugs 2016, 14, 32. [CrossRef] [PubMed]

31. Cao, D.; Lv, X.; Xu, X.; Yu, H.; Sun, X.; Xu, N. Purification and identification of a novel ACE inhibitory peptide from marine alga Gracilariopsis lemaneiformis protein hydrolysate. Eur. Food Res. Technol. 2017, 243, 1829-1837. [CrossRef]

32. Guo, M.; Chen, X.; Wu, Y.; Zhang, L.; Huang, W.; Yuan, Y.; Fang, M.; Xie, J.; Wei, D. Angiotensin I-converting enzyme inhibitory peptides from Sipuncula (Phascolosoma esculenta): Purification, identification, molecular docking and antihypertensive effects on spontaneously hypertensive rats. Process Biochem. 2017, 63, 84-95. [CrossRef]

33. Maruyama, S.; Mitachi, H.; Awaya, J.; Kurono, M.; Tomizuka, N.; Suzuki, H. Angiotensin I-Converting Enzyme Inhibitory Activity of the C-Terminal Hexapeptide of $\alpha$ s1-Casein. Agric. Biol. Chem. Tokyo 1987, 51, 2557-2561. [CrossRef]

34. Escudero, E.; Mora, L.; Toldrá, F. Stability of ACE inhibitory ham peptides against heat treatment and in vitro digestion. Food Chem. 2014, 161, 305-311. [CrossRef] [PubMed]

35. Tagliazucchi, D.; Martini, S.; Shamsia, S.; Helal, A.; Conte, A. Biological activities and peptidomic profile of invitro-digested cow, camel, goat and sheep milk. Int. Dairy J. 2018, 81, 19-27. [CrossRef]

36. Maeno, M.; Yamamoto, N.; Takano, T. Identification of an antihypertensive peptide from casein hydrolysate produced by a proteinase from Lactobacillus helveticus CP790. J. Dairy Sci. 1996, 79, 1316-1321. [CrossRef]

37. Kuba, M.; Tanaka, K.; Tawata, S.; Takeda, Y.; Yasuda, M. Angiotensin I-converting enzyme inhibitory peptides isolated from tofuyo fermented soybean food. Biosci. Biotechnol. Biochem. 2003, 67, 1278-1283. [CrossRef] [PubMed] 
38. Liu, C.; Fang, L.; Min, W.; Liu, J.; Li, H. Exploration of the molecular interactions between angiotensin-I-converting enzyme (ACE) and the inhibitory peptides derived from hazelnut (Corylus heterophylla Fisch.). Food Chem. 2018, 245, 471-480. [CrossRef] [PubMed]

39. Balti, R.; Bougatef, A.; Sila, A.; Guillochon, D.; Dhulster, P.; Nedjar-Arroume, N. Nine novel angiotensin I-converting enzyme (ACE) inhibitory peptides from cuttlefish (Sepia officinalis) muscle protein hydrolysates and antihypertensive effect of the potent active peptide in spontaneously hypertensive rats. Food Chem. 2015, 170, 519-525. [CrossRef] [PubMed]

40. Khan, M.T.H.; Dedachi, K.; Matsui, T.; Kurita, N.; Borgatti, M.; Gambari, R.; Sylte, I. Dipeptide Inhibitors of Thermolysin and Angiotensin I-Converting Enzyme. Curr. Top. Med. Chem. 2012, 12, 1748-1762. [CrossRef] [PubMed]

41. Wu, Q.; Du, J.; Jia, J.; Kuang, C. Production of ACE inhibitory peptides from sweet sorghum grain protein using alcalase: Hydrolysis kinetic, purification and molecular docking study. Food Chem. 2016, 199, 140-149. [CrossRef] [PubMed]

42. Kuramoto, S.; Kaneyoshi, G.; Morinaga, Y.; Matsue, H.; Iwai, K. Angiotensin-Converting enzyme-Inhibitory peptides isolated from pepsin hydrolyzate of apios americana tuber and their hypotensive effects in spontaneously hypertensive rats. Food Sci. Technol. Res. 2013, 19, 399-407. [CrossRef]

43. Duan, X.; Wu, F.; Li, M.; Yang, N.; Wu, C.; Jin, Y.; Yang, J.; Jin, Z.; Xu, X. Naturally occurring angiotensin I-Converting enzyme inhibitory peptide from a fertilized egg and its inhibitory mechanism. J. Agric. Food Chem. 2014, 62, 5500-5506. [CrossRef] [PubMed]

44. Liu, X.; Zhang, M.; Jia, A.; Zhang, Y.; Zhu, H.; Zhang, C.; Sun, Z.; Liu, C. Purification and characterization of angiotensin I converting enzyme inhibitory peptides from jellyfish Rhopilema esculentum. Food Res. Int. 2013, 50, 339-343. [CrossRef]

45. Lin, K.; Zhang, L.; Han, X.; Meng, Z.; Wu, Y.; Zhang, J.; Cheng, D. Quantitative Structure-Activity Relationship Modeling Coupled with Molecular Docking Analysis in Screening of Angiotensin I-Converting Enzyme Inhibitory Peptides from Qula Casein Hydrolysates Obtained by Two-Enzyme Combination Hydrolysis. J. Agric. Food Chem. 2018, 66, 3221-3228. [CrossRef] [PubMed]

46. Wu, H.; He, H.; Chen, X.; Sun, C.; Zhang, Y.; Zhou, B. Purification and identification of novel angiotensin-I-converting enzyme inhibitory peptides from shark meat hydrolysate. Process Biochem. 2008, 43, 457-461. [CrossRef]

47. Marambe, H.K.; Shand, P.J.; Wanasundara, J.P.D. Release of angiotensin I-converting enzyme inhibitory peptides from flaxseed (Linum usitatissimum L.) protein under simulated gastrointestinal digestion. J. Agric. Food Chem. 2011, 57, 9596-9604. [CrossRef] [PubMed]

48. Salampessy, J.; Reddy, N.; Phillips, M.; Kailasapathy, K. Isolation and characterization of nutraceutically potential ACE-Inhibitory peptides from leatherjacket (Meuchenia sp.) protein hydrolysates. LWT-Food. Sci. Technol. 2017, 80, 430-436. [CrossRef]

49. Fujita, H.; Yoshikawa, M. LKPNM: A prodrug-type ACE-inhibitory peptide derived from fish protein. Immunopharmacology 1999, 44, 123-127. [CrossRef]

(C) 2018 by the authors. Licensee MDPI, Basel, Switzerland. This article is an open access article distributed under the terms and conditions of the Creative Commons Attribution (CC BY) license (http:/ / creativecommons.org/licenses/by/4.0/). 